\title{
Screening and Brief Intervention for the use of alcohol and other drugs
}

\author{
Rastreamento e Intervenção Breve para uso de álcool e outras drogas \\ Rastreo e intervención breve para uso de alcohol y otras drogas
}

\section{Ângela Maria Mendes Abreu', Rafael Tavares Jomar", Gunnar Glauco de Cunto Taets"', Maria Helena do Nascimento Souza', Daiane Belisário Fernandes'}

' Universidade Federal do Rio de Janeiro, Anna Nery Nursing School. Rio de Janeiro, Brazil.

"Universidade do Estado do Rio de Janeiro, Nursing School. Rio de Janeiro, Brazil.

"I Universidade Federal do Rio de Janeiro. Macaé, Rio de Janeiro, Brazil.

\begin{abstract}
How to cite this article:
Abreu AMM, Jomar RT, Taets GGC, Souza MHN, Fernandes DB. Screening and Brief Intervention for the use of alcohol and other drugs. Rev Bras Enferm [Internet]. 2018;71(Suppl 5):2258-63.

[Thematic Issue: Mental health] DOI: http://dx.doi.org/10.1590/0034-7167-2017-0444
\end{abstract}

\section{Submission: 06-13-2017 Approval: 05-17-2018}

\section{ABSTRACT}

Objective: to identify the lifetime use of alcohol and other drugs among users of the Family Health Strategy and apply Brief Intervention to problems related to the use of these substances. Method: a descriptive cross-sectional study where 1,031 users of the Family Health Strategy of the city of Rio de Janeiro answered a form with socio-demographic information and the Alcohol, Smoking and Substance Involvement Screening Test. Statistical analysis with simple frequency distribution was performed. Results: the most commonly used drugs in lifetime were alcohol and tobacco; among the illegal drugs, marijuana, hypnotics and cocaine/crack stood out. Those who received most Brief Intervention were users of tobacco, hypnotics, marijuana, cocaine/ crack and alcohol. Conclusion: it is important to detect early problems associated with the use of alcohol and other drugs in Primary Care, since it has the promotion/protection of health and the prevention of diseases as priority health practices.

Descriptors: Alcohol Drinking; Tobacco Use Disorder; Street Drugs; Mass Screening; Family Health Strategy.

\section{RESUMO}

Objetivo: identificar o uso, na vida, de álcool e outras drogas entre usuários da Estratégia Saúde da Família e aplicar Intervenção Breve para problemas relacionados ao uso dessas substâncias. Método: estudo descritivo do tipo transversal onde 1031 usuários da Estratégia Saúde da Família da cidade do Rio de Janeiro responderam um formulário com informações sociodemográficas e o Alcohol, Smoking and Substance Involvement Screening Test. Análise estatística com distribuição de frequências simples foi realizada. Resultados: as drogas mais usadas na vida foram álcool e tabaco; entre as drogas ilícitas, destacaram-se maconha, hipnóticos e cocaína/crack. Os que mais receberam Intervenção Breve foram os usuários de tabaco, hipnóticos, maconha, cocaína/crack e álcool. Conclusão: é importante detectar precocemente problemas associados ao uso de álcool e outras drogas na Atenção Básica, pois ela tem a promoção/proteção da saúde e a prevenção de agravos como práticas sanitárias prioritárias. Descritores: Consumo de Bebidas Alcoólicas; Tabagismo; Drogas Ilícitas; Programas de Rastreamento; Estratégia Saúde da Família.

\section{RESUMEN}

Objetivo: identificar el uso en la vida de alcohol y otras drogas entre usuarios de la Estrategia Salud de la Familia y aplicar una intervención breve para problemas relacionados al uso de esas sustancias. Método: el estudio descriptivo del tipo transversal donde 1031 usuarios de la Estrategia Salud de la Familia de la ciudad de Rio de Janeiro respondieron a un formulario con informaciones sociodemográficas y a el Alcohol, Smoking and Substance Involvement Screening Test. Se realizó un análisis estadístico con distribución de frecuencias simple. Resultados: las drogas más usadas en la vida fueron el alcohol y el tabaco; entre las drogas ilícitas, se destacaron marihuana, hipnóticos y cocaína/crack. Los que más recibieron intervención breve fueron los usuarios de tabaco, hipnóticos, marihuana, cocaína/crack y alcohol. Conclusión: es importante detectar precozmente problemas asociados al uso de alcohol y otras drogas en la atención básica, pues ella tiene la promoción/protección de la salud y la prevención de agravios como prácticas sanitarias prioritarias.

Descriptores: Consumo de Bebidas Alcohólicas; Tabaquismo; Drogas Ilícitas; Programas de Rastreo; Estrategia Salud de la Familia. 


\section{INTRODUCTION}

Alcohol, tobacco and illegal drug use are among the 20 largest risk factors for health problems identified by the World Health Organization, which estimates that tobacco accounts for $8.7 \%$ of all deaths and $3.7 \% \%$ of the global disease burden - measured by disability adjusted lifetime years (DALYs) - and that alcohol accounts for $3.8 \%$ of deaths and $4.5 \%$ of DALYs; already illegal drugs would account for $0.4 \%$ of deaths and $0.9 \%$ of DALYs ${ }^{(1)}$.

The policy of the Ministério da Saúde (Ministry of Health) for integral care for users of alcohol and other drugs prioritizes that therapeutic and/or preventive actions directed at people who use these substances and their families are carried out in the community, establishing that care programs aimed at this Primary Care as one of its main components ${ }^{(2)}$.

In Brazil, Primary Care is characterized by a set of health actions, ranging from health promotion and prevention of injuries to rehabilitation, with the objective of developing care that impact on the health situation of people and on the determinants and constraints of health of collectivities. The Primary Care - which is effective through the Family Health Strategy (FHS) should be the preferred contact of users, the main gateway and communication center with the entire health care network ${ }^{(3)}$.

Therefore, it is necessary not only to describe the characteristics of the demand related to the problems arising from the use of alcohol and other drugs that reach Primary Care ${ }^{(4)}$, but also to identify at an early stage people with low risk of using these substances in this setting, since it is considered ideal for the screening of such use, as well as problems arising from it ${ }^{(5-9)}$.

The use of concise and short-term therapeutic techniques has been an important part of the spectrum of care available for the treatment and approach of alcohol and other drug us$\mathrm{ers}^{(5-7,9)}$. Among them, Brief Intervention (BI) stands out: a technique aimed at modifying the conduct of users of psychoactive substances over the most frequently used that causes them problems, helping them to understand that such use puts them at risk, thus motivating them to reduce or stop using drugs ${ }^{(10-11)}$.

The BI has been developed especially for people with moderate risk of use, in other words, those who are not dependent on alcohol or other drugs but who consume such substances in a dangerous or harmful way - which can lead to problems both health and social, legal, labor or economic. The BI has been identified as effective in identifying users with low and moderate risk of use and also to influence their habits, having the advantage of being able to be applied not only by specialists but by any trained and skilled health professional ${ }^{(10-11)}$.

Particularly in Primary Care, the $\mathrm{Bl}$ consists of offering a brief feedback and advice that seeks to motivate the users of low and moderate risk psychoactive substances to change their consumption behavior, creating a link between their current habits of use and the risks/damage associated with it ${ }^{(11)}$. It is worth emphasizing that the results of a systematic review have shown that the most appropriate place for the application of $\mathrm{Bl}$ is the Primary Care ${ }^{(12)}$.

The lack of awareness among health professionals about the use of alcohol and other drugs as an important public health issue leads them to stigmatize abusive users and not to engage with coping strategies in their professional routine, such as the $\mathrm{IB}^{(12)}$. Given this assertion and considering the importance of Primary Care in preventing damages associated with the use of psychoactive substances ${ }^{(4-11,13)}$, the present study intends to highlight the importance of professionals working in the FHS, especially nurses, to screen the use of alcohol and other drugs and apply $\mathrm{BI}$, since this technique is useful to prevent problems related to the use of these substances ${ }^{(6)}$.

\section{OBJECTIVE}

To identify the lifetime use of alcohol and other drugs among FHS users and to apply $\mathrm{BI}$ in problems related to the use of these substances.

\section{METHOD}

\section{Ethical aspects}

The ethical procedures of the present study are represented by the approval of the Research Ethics Committee of the Secretaria Municipal de Saúde (Municipal Health Secretariat) of Rio de Janeiro State and the signing of the Informed Consent Term of the subjects who accepted to participate in it.

\section{Design, place and period}

A descriptive cross-sectional study was carried out between the months of September 2013 and July 2014, together with the users of two Basic Health Units (BHU) that function in the FHS model, located in the Complexo do Alemão (Complexo do Alemão is a neighborhood and a group of favelas in the North Zone of Rio de Janeiro State, Brazil).

\section{Population and sample}

The BHU in question consisted of 12 Family Health teams, responsible for the health care of about 40,000 people. A nonprobabilistic sample of 1031 individuals of both gender and age greater than or equal to 18 years who, in the morning from Monday to Friday, sought care for any reason, was approached by nursing academics duly trained to collect data, in the waiting rooms of the scenarios in which the study was developed. As indicated by the nurse of the respective Family Health team, later confirmed in the chart, individuals with some mental/cognitive disabilities and pregnant women were not considered for participation.

\section{Study protocol}

The subjects' individual approach did not follow the systematic criteria and was randomly performed by nursing students, who provided information about the nature and objectives of this research, as well as about voluntary participation. Following, in reserved places of the $\mathrm{BHU}$, interviews were conducted without the presence of third parties. There were no refusals to participate in the study.

The tools used were: a form that included socio-demographic information (gender, age group, marital status, schooling level and monthly family income) and Alcohol, Smoking and Substance Involvement Screening Test (ASSIST) ${ }^{(7)}$ - a screening questionnaire to detect people who use psychoactive substances. 
Elaborated mainly to detect the consumption of drugs (marijuana, cocaine/crack, amphetamines, sedatives, hallucinogens, inhalants and opioids), ASSIST can also be used to detect alcohol and tobacco consumption where consumption is high ${ }^{(11)}$.

The ASSIST is already validated to use in Brazil with adequate psychometric qualities ${ }^{(13)}$, and was chosen to be used in the study because it is mainly aimed at use in Primary Care. Comprising eight questions on the use of nine classes of substances, it addresses frequency of use (in lifetime and in the last three months), problems related to use, concern about the use by close people, impairment in performing tasks expected, unsuccessful attempts to cease or reduce use, feeling compulsive, and feeling of injecting ${ }^{(7)}$.

The ASSIST scores range from 0 to 8 , and the total sum can vary from 0 to 39 . The final sum of the responses scores the use of each substance as low (0-10 for alcohol, 0-3 for others drugs), moderate (11-26 for alcohol, 4-26 for other drugs) or high risk ( $\geq 27)$. Individuals classified as moderate-risk users should receive $\mathrm{BI}$, and high-risk users should be referred for specialized treatment. Those classified as low-risk users should receive general health advice ${ }^{(10)}$.

According to recommendations in the ASSIST manual for use of $\mathrm{BI}$ in Primary Care ${ }^{(10)}$, individuals classified as low-risk users received general health advice and those classified as moderate risk users received $\mathrm{BI}$ from the interviewers, who and concluded the 20-hour course "Alcohol and Drug Training: Screening, Evaluation and Treatment Plan in Primary Care" offered by the Universidade Federal do Rio de Janeiro (UFRJ). On the other hand, those individuals classified as high-risk users who received formal referral to the BHU so that their professionals, who also completed the previously mentioned course, received them and provided referral to a specialized center.

\section{Statistics analysis}

The information in the collection tools was entered in the Epi-Info version 3.5.1 software, where analyzes were performed with simple frequency distribution to describe the sample and the lifetime use of alcohol and other drugs, as well as the need for application of $\mathrm{BI}$ to problems related to the use of these substances.

\section{RESULTS}

Table 1 shows that the majority of respondents were female (76.4\%), aged between 18 and 34 (45.5\%), had incomplete elementary school (35.8), were married (60.7\%) and had monthly family income between 1 and 2 minimum wages (49.6\%).

Table 2 shows the drugs already used in lifetime by the interviewees. Those that presented the highest frequency were alcohol $(70.7 \%)$ and tobacco $(46.4 \%)$. Among the most frequently lifetime used illegal drugs were marijuana (8.4\%), hypnotics $(4.6 \%)$ and cocaine/crack (4.2\%).

According to Table 3, among those who have tried with drugs in lifetime, the users of tobacco $(n=169,16.4 \%)$, of alcohol $(n=81,7.9 \%)$, hypnotics $(n=14,1.4 \%)$, marijuana $(n=12$, $1.2 \%)$ and cocaine/crack $(n=09 ; 0,9 \%)$.
Table 1 - Socio-demographic characteristics of the users of the Family Health Strategy, Rio de Janeiro State, Brazil, 2013/2014 ( $\mathrm{N}=1031)$

\begin{tabular}{|c|c|c|}
\hline Variables & $\mathbf{n}$ & $\%$ \\
\hline \multicolumn{3}{|l|}{ Gender } \\
\hline Female & 788 & 76.4 \\
\hline Male & 243 & 23.6 \\
\hline \multicolumn{3}{|l|}{ Age bracket (years) } \\
\hline $18-34$ & 469 & 45.5 \\
\hline $35-59$ & 428 & 41.5 \\
\hline$\geq 60$ & 134 & 13.0 \\
\hline \multicolumn{3}{|l|}{ Marital status* } \\
\hline Married/Living together & 625 & 60.7 \\
\hline Single & 229 & 22.2 \\
\hline Divorced/Separated & 95 & 9.2 \\
\hline Widow(er) & 81 & 7.9 \\
\hline \multicolumn{3}{|l|}{ Schooling level* } \\
\hline None & 39 & 3.8 \\
\hline Incomplete elementary school & 364 & 35.8 \\
\hline Complete elementary school & 172 & 16.9 \\
\hline Complete high school & 159 & 15.6 \\
\hline Incomplete high school & 218 & 21.5 \\
\hline Inomplete higher education & 36 & 3.5 \\
\hline Complete higher education & 29 & 2.9 \\
\hline \multicolumn{3}{|l|}{ Monthly family wage* } \\
\hline None & 23 & 2.3 \\
\hline$<1$ Minimum wage & 148 & 14.5 \\
\hline $1 \vdash 2$ Minimum wages & 505 & 49.6 \\
\hline $2 \vdash 3$ Minimum wages & 137 & 13.5 \\
\hline $3 \vdash 4$ Minimum wages & 65 & 6.4 \\
\hline$\geq 4$ Minimum wages & 139 & 13.7 \\
\hline
\end{tabular}

Note: * The ones without information were excluded.

Table 2 - Frequency of lifetime drugs use among users of the Family Health Strategy, Rio de Janeiro State, Brazil, 2013/2014 ( $=1031)$

\begin{tabular}{lcccc}
\hline & \multicolumn{5}{c}{ Lifetime drugs use } \\
Drugs & & Yes & No & \\
& $\mathbf{n}$ & $\mathbf{\%}$ & $\mathbf{n}$ & \\
\hline & & & & \\
Alcohol & 729 & 70.7 & 302 & 29.3 \\
Tobacco & 478 & 46.4 & 553 & 53.6 \\
Marijuana & 87 & 8.4 & 944 & 91.6 \\
Hypnotics & 47 & 4.6 & 984 & 95.4 \\
Cocaine/Crack & 43 & 4.2 & 988 & 95.8 \\
Amphetamines & 23 & 2.2 & 1008 & 97.8 \\
Opioids & 10 & 1.0 & 1021 & 99.0 \\
Inhalants & 09 & 0.9 & 1022 & 99.1 \\
Hallucinogens & 03 & 0.3 & 1028 & 99.7 \\
& & & & \\
\hline
\end{tabular}


Table 3 - Frequency of application of Brief Intervention among users of the Family Health Strategy, according to the type of drug used, Rio de Janeiro State, Brazil, 2013/2014 (N=1031)

\begin{tabular}{lcc}
\hline Drugs* & $\mathbf{n}$ & \% \\
\hline Alcohol & & \\
$\quad$ Brief Intervention applied & 81 & 7.9 \\
$\begin{array}{l}\text { Tobacco } \\
\text { Brief Intervention applied }\end{array}$ & 169 & 16.4 \\
$\begin{array}{l}\text { Marijuana } \\
\text { Brief Intervention applied }\end{array}$ & 12 & 1.2 \\
$\begin{array}{l}\text { Hypnotics } \\
\text { Brief Intervention applied }\end{array}$ & 14 & 1.4 \\
$\begin{array}{l}\text { Cocaine/Crack } \\
\text { Brief Intervention applied }\end{array}$ & 09 & 0.9 \\
Amphetamines \\
Brief Intervention applied \\
$\begin{array}{l}\text { Opioids } \\
\text { Brief Intervention applied }\end{array}$ \\
$\begin{array}{l}\text { Inhalants } \\
\text { Brief Intervention applied }\end{array}$ & 02 & 0.2 \\
\hline
\end{tabular}

Note: *It was not necessary to apply the Brief Intervention among the ones who have already tried hallucinogens.

\section{DISCUSSION}

In the present study, it was observed that the most used drugs in lifetime by the interviewees were alcohol and tobacco; among the most commonly used illegal drugs were marijuana, hypnotics and/or cocaine/crack. Regarding the need to apply $\mathrm{BI}$ to problems related to the use of psychoactive substances, the individuals who stood out were users of alcohol, tobacco, hypnotics, marijuana and cocaine/crack.

The analysis of patterns of alcohol consumption and other drugs of the Brazilian urban population aged between 16 and 65 years in 2005 indicated alcohol as the most frequently used substance, with a report of regular use in lifetime by $18 \%$ of respondents. The consumption of illegal drugs in lifetime was reported by $8.9 \%$ of the interviewees. Among these, $80.1 \%$ used marijuana/hashish the first time they used illegal drugs and $6 \%$ used cocaine powder aspirate $(6 \%)$, with rare use of injectable drugs ${ }^{(14)}$.

Results from the II National Survey of Alcohol and Drugs developed between the years 2011 and 2012 in 149 Brazilian municipalities - show that $7 \%$ of adults have tried marijuana and $3 \%$ have used this drug in the last 12 months $^{(15)}$. Regarding cocaine, the same study indicates that $3.9 \%$ of adults have already tried this substance and $1.7 \%$ have used it in the last 12 months. Regarding crack, $1.5 \%$ of adults have tried it and $0.8 \%$ have used it in the last 12 months $^{(16)}$.

In a survey carried out in the cities of São Paulo and Curitiba (Brazil), alcohol and tobacco were the main legal substances of abuse, with expressive prevalence among adults with Primary Care services belonging to the FHS and other non-hospital services. $50.9 \%$ and $33.3 \%$, respectively); marijuana $(28.3 \%)$ and cocaine $(6.1 \%)$ were the main illegal substances causing problems $^{(13)}$.

The study identified that $4.6 \%$ of the interviewees had used hypnotics in their lives, $1.2 \%$ had to receive $\mathrm{BI}$ and $0.2 \%$ had been referred to the $\mathrm{BHU}$ in order to receive specialized treatment, due to the high risk that the use of this substance represented for your health. A recent integrative review ${ }^{(17)}$ showed that the majority of users of Brazilian Primary Care who make abusive use of hypnotics and are routinely attend BHU and that, although most are not suffering from a mental disorder that justifies medical prescription, they have direct access to these professionals, it becomes easy to require such concomitant prescription of medicines to treat their other underlying diseases. The fact that the sample of this study is mostly of female $(76.4 \%)$, helps explain the significant percentage of hypnotic use in lifetime, since the population that consumes the substance most, including abusive use, is the female: the one that most seeks and frequents the BHU ${ }^{(17)}$.

It is important to emphasize that Primary Care takes an important place in the health system, since its professionals provide a comprehensive approach with continuous health care and present skills for health promotion actions and disease prevention. They are also seen as professional providers of reliable and quality information that can establish a first contact with groups that are at high risk of problems with alcohol and drugs ${ }^{(7)}$.

There is evidence that if Primary Care professionals investigate risk factors for alcohol and other drug use, patients feel more comfortable talking about their problems with the use of these substances and consider changing their use behavior, more easily. Therefore, the early detection of people with low risk of use of psychoactive substances in Primary Care can further increase the effectiveness of the interventions performed ${ }^{(7)}$, just as BI.

In the present study, only one type of substance (hallucinogens) did not present users with a need for BI application; with expressive frequencies among all other substances. Therefore, we believe in the relevance of the early detection of the problems associated with the use of alcohol and other drug risks in Primary Care allied to $\mathrm{BI}$, since this setting has the promotion/protection of health and the prevention of diseases as priority sanitary practices.

A randomized controlled trial investigating the efficacy of ASSIST-associated BI for moderate-risk drug use among users of Primary Care services in Australia, Brazil, the United States and India found that participants who received a BI for the use of psychoactive substances significantly reduced the ASSIST score after three months compared to the control group participants. In addition, after receiving $\mathrm{BI}$, more than $80 \%$ of participants reported intention to reduce drug use by making positive comments about the impact of $\mathrm{BI}$ on their health behavior ${ }^{(11)}$.

Throughout the world, governments have emphasized the importance of developing initiatives, such as those described here, to encourage the reduction of alcohol and drug abuse, to empower human resources for health promotion, and to treat, rehabilitate, and promote social integration for those affected by psychoactive substance abuse.

Brazilian experience in training Primary Care professionals ${ }^{(18)}$ pointed out that the training procedures showed a significant participation in changing the vision of the problem of alcohol 
and drug use as belonging to the private and moral sphere to a less reductionist view that considers others factors in the triggering of this problem, thus allowing preventive actions to be carried out by professionals trained in their services.

Although problems related to alcohol and other drug use are prevalent in a number of countries and are considered a serious public health problem, very little has been done to increase health professionals' access to information on specific skills to detect the problem early and intervene effectively ${ }^{(18)}$. Therefore, we believe that the present study did not only contribute to the better knowledge of the use of psychoactive substances among users of Primary Care, but also contributed to the qualification of professionals of the Brazilian Unified Health System (Sistema Único de Saúde) in the detection and early intervention of problems related to the use alcohol and other drugs.

Systematic review ${ }^{(12)}$ states that Primary Care, besides being the first contact of the individual, the family and the community with the health system, is considered the best environment for the application of preventive measures, especially those directed at risk users of alcohol, since the stigma with the users of psychoactive substances is lower and, consequently, their resistance to approach and orientation regarding the problem will also be less. It is worth noting that in small Brazilian municipalities, the impact of screening and $\mathrm{BI}$ strategies for problems related to alcohol and other drug use may be even greater, since Primary Care is the main, if not the only, form of supply of public health services ${ }^{(12)}$.

Therefore, we emphasize the importance of the training of Primary Care professionals, with emphasis on the FHS, to reduce alcohol and drug abuse with a view to promoting health, which should be recognized as important, especially by managers and not only by professionals. Considering that health professionals are key players in identifying alcohol users and other drug users, and we ratify the need for training of Primary Care professionals to screen for psychoactive substance abuse and the use of $\mathrm{BI}$ with a view to reducing/terminating such consumption, as well as minimizing the problems related to such use.

In order to do so, it is important to highlight the importance of approaching screening, assessment and BI tools for problems related to alcohol and other drugs as a theme in health care curricula in order to equip future professionals with prevention and intervention tools related to the use of psychoactive substance risk ${ }^{(19)}$.

Because of its opportunity to work in a variety of settings, nurses, in particular, occupy a prominent position, as they can apply to $\mathrm{BI}$, in order to create an opportunity for preventive intervention for injuries caused by the use of alcohol and other drugs. Especially nurses working in the FHS, who can incorporate in routine nursing consultations a brief moment to identify patients with problems related to the use of psychoactive substances. Whether in consultations with patients with hypertension, diabetes, leprosy, tuberculosis or with pregnant women in prenatal consultations, the nurse can help people who can benefit from the reduction or cessation of the use of these substances ${ }^{(6)}$.

In this perspective, the nurse can apply the BI that will assist in the protection and promotion of individuals' health, since they have been reported as effective in reducing the use of alcohol and other drugs in Primary Care ${ }^{(11)}$. In this way, nurses working in this scenario will act preventively, exercising their professional autonomy in a critical and active way towards an increasingly responsible and autonomous professional practice ${ }^{(6)}$.

Finally, we emphasize the importance of developing other studies aiming to know the magnitude of alcohol and other drug use in Primary Care that can subsidize the strengthening of health policies aimed at the populations served in the scope of the FHS and also of intervention studies to assess whether $\mathrm{BI}$ influences drug use habits among Brazilian Primary Care users.

\section{Study limitation}

We did not intend to describe the use of alcohol and other drugs according to socio-demographic characteristics of the studied sample, but to characterize them in a global way, thus offering an overview of this phenomenon among the individuals who sought the services offered by the BHU in which it was developed. Thus, it presents some limitations: its transversal design makes impossible the evaluation of the effectiveness of the applied $\mathrm{BI}$; the possible occurrence of memory bias; the fact that it was carried out in only one area of the city of Rio de Janeiro attached to the FHS; the sample studied was of convenience, which limits its generalization potential and; the high frequency of female participants, who may have underestimated the frequencies of use in substance lifetime, as well as the need for $\mathrm{BI}$ application among the interviewees. Thus, we recommend that future studies be conducted with representative samples of individuals from both FHS user genders in order to identify possible gender differences in alcohol and other drug use frequencies and in the application of BI.

\section{Contributions to the sector of nursing/health}

The use of ASSIST with the application of IB, a soft and low-cost technology ${ }^{(6,9-11)}$, has proved to be a facilitator for the development of activities aimed at health orientation and prevention of diseases related to abuse alcohol and other drugs at the main gateway to the Brazilian health system. This study highlights, finally, the importance of the nurse working in the FHS to screen the use of alcohol and other drugs, and to apply $\mathrm{BI}$, since this technique is useful for the practice of this professional in the prevention of problems related to the use of psychoactive substances ${ }^{(6)}$.

\section{CONCLUSION}

We have observed in this study that the most used drugs in lifetime by the interviewees were alcohol (70.7\%) and tobacco $(46.4 \%)$; among the most commonly used illegal drugs were marijuana $(8.4 \%)$, hypnotics $(4.6 \%)$ and cocaine/crack (4.2\%). The application of BI was necessary for some users of psychoactive substances, especially those who used alcohol $(7.9 \%)$, tobacco $(16.4 \%)$, hypnotics $(1.4 \%)$, marijuana $(1.2 \%)$, and cocaine/crack $(0.9 \%)$.

\section{FUNDING}

This study was funded by the Ministério da Saúde (Ministry of Health), through the Programa de Educação pelo Trabalho para a Saúde (Advancing SocialWork Education for Health Impact)/ Family Health Program. 


\section{REFERENCES}

1. World Health Organization-WHO. Global Health Risks[Internet]. Genebra: WHO; 2009[cited 2017 May 25]. Available from: http:// www.who.int/healthinfo/global_burden_disease/GlobalHealthRisks_report_full.pdf

2. Brasil. Ministério da Saúde. A política do ministério da saúde para atenção integral a usuários de álcool e outras drogas[Internet]. Brasília: Ministério da Saúde; 2004[cited 2017 May 25]. Available from: http://bvsms.saude.gov.br/bvs/publicacoes/politica_ atencao_alcool_drogas.pdf

3. Brasil. Ministério da Saúde. Política nacional de atenção básica[Internet]. Brasília: Ministério da Saúde; 2012 [cited 2017 May 25]. Available from: http://189.28.128.100/dab/docs/publicacoes/geral/pnab.pdf

4. Abreu AMM, Parreira PMSD, Souza MHN, Barroso TMMDA. Profile of consumption of psychoactive substances and its relationship to sociodemographic characteristics: a contribution to a brief intervention in primary health care, Rio de Janeiro, Brazil. Texto Contexto Enferm[Internet]. 2016[cited 2017 May 25];25(4):e1450015. Available from: http://www.scielo.br/pdf/tce/v25n4/01040707-tce-25-04-1450015.pdf

5. Guimarães FJ, Fernandes AFC, Pagliuca LMF. Interventions to cope with alcohol abuse: integrative review. Rev Eletron Enferm[Internet]. 2015[cited 2017 May 25];17(3):1-12. Available from: https://doi.org/10.5216/ree.v17i3.29290

6. Jomar RT, Abreu AMM. Intervenções breves para uso problemático de álcool: potencial de aplicação na prática do enfermeiro. Rev Enferm UERJ[Internet]. 2012[cited 2017 May 25];20(3):391-95. Available from: http://www.e-publicacoes.uerj.br/index.php/ enfermagemuerj/article/view/810/2890

7. Humeniuk R, Henry-Edwards S, Ali R, Poznyak V, Monteiro MG. The alcohol, smoking and substance involvement screening test (ASSIST): manual for use in primary care[Internet]. Genebra: WHO; 2010[cited 2017 May 25]. Available from: http://apps.who. int/iris/bitstream/10665/44320/1/9789241599382_eng.pdf

8. Jomar RT, Paixão LAR, Abreu AMM. Alcohol Use Disorders Identification Test (AUDIT) e sua aplicabilidade na atenção primária à saúde. Rev APS[Internet]. 2012[cited 2017 May 25];15(1):113-7. Available from: https://aps.ufjf.emnuvens.com.br/aps/article/ view/1467/598

9. Gonçalves MAS, Ferreira PS, Abreu AMM, Pillon SC, Jezus SV. Estratégias de rastreamento e intervenções breves como possibilidades para a prática preventiva do enfermeiro. Rev Eletron Enferm[Internet]. 2011[cited 2017 May 25];13(2):355-60. Available from: https://www.fen.ufg.br/revista/v13/n2/v13n2a23.htm

10. Humeniuk R, Henry-Edwards S, Ali R, Poznyak V, Monteiro MG. The ASSIST-linked brief intervention for hazardous and harmful substance use: manual for use in primary care[Internet]. Genebra: WHO; 2010[cited 2017 May 25]. Available from: http://apps. who.int/iris/bitstream/10665/44321/1/9789241599399 eng.pdf?ua =1

11. Humeniuk R, Dennington $\mathrm{V}$, Ali RL. The effectiveness of a brief intervention for illicit drugs linked to the ASSIST screening test in primary health care settings: a technical report of phase III findings of the WHO ASSIST randomised controlled trial[Internet]. Genebra: WHO; 2008[cited 2017 May 25]. Available from: http://www.who.int/substance abuse/activities/assist technicalreport phase3_final.pdf

12. Pereira MO, Anginoni BM, FerreiraNC, Oliveira MAF, Vargas D, Colvero LA. Efetividade da intervenção breve para o uso abusivo de álcool na atenção primária: revisão sistemática. Rev Bras Enferm[Internet]. 2013[cited 2017 May 25];66(3):420-28. Available from: http://www.scielo.br/pdf/reben/v66n3/a18v66n3.pdf

13. Henrique IFS, Micheli D, Lacerda RB, Lacerda LA, Formigoni MLOS. Validação da versão brasileira do teste de triagem do envolvimento com álcool, cigarro e outras substâncias (ASSIST). Rev Assoc Med Bras[Internet]. 2004[cited 2017 May 25];50(2):199206. Available from: http://www.scielo.br/pdf/ramb/v50n2/20784.pdf

14. Bastos FI, Bertoni N, Hacker MA. Drug and alcohol use: main findings of a national survey, Brazil 2005. Rev Saúde Pública[Internet]. 2008[cited 2017 May 25];42(Supl-I):109-17. Available from: http://www.scielo.br/pdf/rsp/v42s1/en_13.pdf

15. Instituto Nacional de Ciência e Tecnologia para Políticas Públicas do Álcool e Outras Drogas (INPAD). Portal do INPAD[cited 2017 May 25]. Available from: http://inpad.org.br/wp-content/uploads/2013/04/Press_Maconha_Slte1.pdf

16. Abdalla RR, Madruga CS, Ribeiro M, Pinsky I, Caetano R, Laranjeira R. Prevalence of cocaine use in Brazil: data from the II Brazilian national alcohol and drugs survey (BNADS). Addict Behav[Internet]. 2014[cited 2017 May 25];39(1):297-301. Available from: http:// www.sciencedirect.com/science/article/pii/S0306460313003213

17. Moura DCN, Pinto JR, Martins P, Pedrosa KA, Carneiro MGD. Uso abusivo de psicotrópicos pela demanda da Estratégia Saúde da Família: revisão integrativa da literatura. Sanare[Internet]. 2016[cited 2017 May 26];15(2):136-44. Available from: https://sanare. emnuvens.com.br/sanare/article/viewFile/1048/594

18. Souza ICW, Ronzani TM. Álcool e drogas na atenção primária: avaliando estratégias de capacitação. Psicol Estud[Internet]. 2012[cited 2017 May 25];17(2):237-46. Available from: http://www.scielo.br/pdf/pe/v17n2/v17n2a06.pdf

19. Souza J, Luis MAV, Corradi-Webster CM. Brief interventions and tools for nursing care: descriptive and exploratory study. O Braz J Nurs[Internet]. 2013[cited 2017 May 25];12(1):21-32. Available from: http://www.objnursing.uff.br/index.php/nursing/article/ view/3504. 